\title{
К ВОПРОСУ ОБ ИНВАЗИВНОМ ВРЕДИТЕЛЕ ВЯЗОВ -
} APROCEROS LEUCOPODA

\section{ON INVASIVE PEST OF ULMUS - APROCEROS LEUCOPODA}

\section{O. Filimonova}

Summary. This work examined some features of the biology and ecology of the invasive species - Aproceros leucopoda Takeuchi, 1939 (Hymenoptera: Argidae) in the Samara region, as well as presented the results of population dynamics. This species is found both in recreational and landscaping plantations, and in forest belts. Local foci of an increased number of invaders are fixed along federal highways in plantations consisting of a monoculture of elm. It contributes to the increase in the number of pests hot and dry weather during the growing season.

Keywords: protective plantings, Ulmus, invasive species, Aproceros leucopoda.
Филимонова Ольга Сергеевна

Соискатель, ФНЦ агроэкологии, комплексных мелиораций и защитного лесоразведения Российской академии наук (Волгоград) olga_filimonova_88@rambler.ru

Аннотация. В данной работе рассмотрены некоторые особенности биологии и экологии инвазивного вида - ильмового пилильщика-зигзаг Aproceros leucopoda Takeuchi, 1939 (Hymenoptera: Argidae) в условиях Самарской области, а также представлены результаты динамики численности популяции. Данный вид встречается как в рекреационно-озеленительных насаждениях, так и в лесополосах. Локальные очаги повышенной численности инвайдера фиксируются вдоль федеральных автотрасс в насаждениях, состоящих из монокультуры вяза. Способствует увеличению численности вредителя жаркая и сухая погода в течение вегетационного периода.

Ключевые слова: защитные насаждения, Ulmus, инвазивный вид, Aproceros leucopoda.

расселения, что делает данный вид наиболее вредоносным для вязов европейской части России.

В настоящее время локальные очаги повышенной численности $A$. leucopoda нами фиксируются с 2016 г. в придорожных лесополосах вдоль автотрасс Самарской области.

Характер распространения и степень вредоносности пилильщика-зигзаг в новых условиях обитания изучены недостаточно. В литературе имеются лишь фрагментарные сведения о биологии и экологии вредителя $[16,17]$. В этой связи целью работы стало изучение особенностей пространственного распределения и количественного обилия инвайдера в новых экологических условиях.

\section{Материалы и метолы исслеАования}

Наблюдения были проведены автором в весенне-летний период с 2017 по 2020 гг. на территории Самарской области. Были обследованы рекреационно-озеленительные насаждения (лесопарки, парки, скверы, внутриквартальные), лесные полосы (придорожные, полезащитные) и отдельно стоящие деревья вяза. При этом в насаждениях каждой категории были выделены по три постоянных учетных площадки, на которых обследовали по 5 модельных дерева. Сбор материала 
Таблица 1. Плотность и вредоносность Aproceros leucopoda на деревьях разного возраста

\begin{tabular}{|l|l|l|} 
Возраст дерева & $\begin{array}{l}\text { Численность личинок, } \\
\text { шт./ед. учета }\end{array}$ & Дефолиация,\% \\
\hline $15-20$ лет & $24,4 \pm 2,06$ & 99,47 \\
\hline $25-30$ лет & $21,8 \pm 1,97$ & 90,34 \\
\hline $60-65$ лет & $17,0 \pm 1,46$ & 85,33 \\
\hline
\end{tabular}

Таблица 2. Влияние климатических факторов на плотность популяции Aproceros leucopoda в насаждениях Самарской области

\begin{tabular}{|c|c|c|c|}
\hline $\begin{array}{l}\text { Максимальная температура } \\
\text { воздуха, 'C }\end{array}$ & $\begin{array}{l}\text { Среднемесячная } \\
\text { температура воздуха, }{ }^{\circ} \mathrm{C}\end{array}$ & Количество осадков, мм & $\begin{array}{l}\text { Численность личинок, } \\
\text { шт./ед. учет }\end{array}$ \\
\hline \multicolumn{4}{|l|}{2017 год, июль } \\
\hline 35,3 & 21,3 & 30 & $8,84 \pm 1,27$ \\
\hline \multicolumn{4}{|l|}{2018 год, июль } \\
\hline 36,5 & 23,9 & 94 & $2,50 \pm 0,57$ \\
\hline \multicolumn{4}{|l|}{2019 год, июль } \\
\hline 30,2 & 20,5 & 28 & $5,67 \pm 0,43$ \\
\hline \multicolumn{4}{|l|}{2020 год, июль } \\
\hline 37,4 & 24,3 & 19 & $10,58 \pm 1,52$ \\
\hline
\end{tabular}

производился с верхней, средней и нижней частях кроны U. pumila, U. glabra и U. laevis. Долю поврежденных листьев определяли, как отношение количества поврежденных листьев к общему числу учтенных листьев (\%). Данные о температуре воздуха и количеству осадков были получены с метеорологической станции Самарской области (широта 53,25; долгота 50,22; высота над уровнем моря 139 м).

\section{Полученные результаты и их обсу»}

Ильмовый пилильщик-зигзаг является партеногенетическим видом. Повсеместно на территории Самарской области в очагах размножения вредителя встречались только самки. В лабораторных условиях через 28 часов после выхода из кокона самка приступает к откладке яиц, которые помещаются в краевые зубчики листьев вяза. Плодовитость самок в очагах массового размножения в среднем составляет 12,9 $\pm 1,3$; максимальна - 37.

На одной листовой пластинке зафиксировано в среднем 4,67士0,42 яйца. Продолжительность развития яиц колеблется от 6 до 8 дней. Отродившиеся личинки питаются исключительно листвой вязов в течение 12-14 дней, после чего окукливаются в коконе, расположенном на нижней стороне листа. На одной листовой пластинке в зависимости от ее площади может развиваться от 2 до 9 особей. В период питания личинки пилильщика могут полностью уничтожать листовую пластинку, при этом остается только центральная жилка.

Вредоносность $A$. leиcopoda усиливается способностью в условиях Самарской области развиваться в 3 поколениях, что приводит к полной дефолиации кроны деревьев. Высокая степень поврежденности ассимиляционного аппарата вязов ослабляет жизнестойкость деревьев и может привести к полной гибели древостоя.

Личинки вредителя неравномерно распределяются по кроне дерева. Основная численность личинок приурочена к наиболее освещенной верхней части кроны

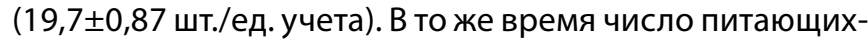
ся особей в средней и нижней частях кроны ниже на 20 и 53\% соответственно. Аналогичная картина распределения вредителя по кроне отмечена в насаждениях Румынии, где исследователи отмечают наибольшую поврежденность листвы в верхней части кроны деревьев [2].

Наибольшую опасность инвайдер представляет для молодых деревьев, крона которых практически полностью уничтожается личинками вредителя (таблица 1). С увеличением класса возраста плотность личинок на вязах снижается на 10,7 и 30,3\%, тогда как поврежденность кроны уменьшается на 9,2 и 14,2\%.

Преимущественно инвайдер формирует локальные очаги в придорожных лесополосах продуваемой конструкции (11-26 экземпляра/ед. учета), состоящих 
из монокультуры вяза. Здесь степень повреждения ассимиляционного аппарата $U$. pumila была максимальной (95-100\%). В многопородных полезащитных лесных полосах плотной конструкции численность вредителя значительно ниже (5-12 экземпляра/ед. учета). При этом в насаждениях данной категории отмечается агрегированное распределение личинок филлофага, что обусловлено пространственной гетерогенностью кормового растения и неоднородностью абиотических факторов. В рекреационно-озеленительных насаждениях количественное обилие личинок пилильщика составляет 1-3 экземпляра/ед. учета.

Фактором, способствующим увеличению численности вредителей в условиях Самарской области, выступает жаркая засушливая погода в вегетационный период (таблица 2).

Так, в 2020 году, характеризующийся избытком солнечной радиации и низким количеством осадков, наблюдается резкое повешение плотности популяции пилильщика, вследствие физиологического угнетения и ослабления сопротивляемости растений. При этом в очагах массового размножения количество личинок вредителя на 100 листьев колеблется от 2 до 30 особей. В более влажные годы численность инвайдера ниже. В 2018 г. наблюдалось превышение количества выпавших осадков на $164 \%$ от нормы, что повлияло на состояние популяции. В данный год происходит паде- ние численности пилильщика на 71,7\% по сравнению с предыдущим годом наблюдений. Смертность второго поколения в период яйцо-личинки младшего возраста превысила 98\%. Вероятно, высокая влажность способствует распространению возбудителей различных болезней и гибели личинок $A$. leucopoda от них.

\section{Зак^ючение}

В настоящее время пилильщик-зигзаг в защитных насаждениях степной зоны Самарской области является важнейшим листогрызущим вредителем вязов. Количественное обилие и уровень вредоносности инвайдера значительно изменяется в зависимости от категории и возраста насаждений. Погодные условия оказывают косвенное влияние на популяцию пилильщика вызывая изменения численности особей. Количественное обилие вредителя возрастает в засушливый период.

Пространственное размещение $A$. leucopoda определяется уровнем инсоляции. Данный вид предпочитает заселять наиболее освещенную часть кроны.

Высокая вредоносность и широкое распространение адвентивного вида $A$. leucopoda в новых экологических условиях свидетельствует о его натурализации и требует активизации работ по изучению вредителя для разработки эффективных мероприятий по подавлению численности вредителя.

\section{ЛИТЕРАТУРА}

1. Lopez-Vaamonde C. Glavendekic M., Paiva M.R. Invaded habitats // BioRisk. 2010. T. 4. P. 45-50.

2. Aprocerus leucopoda (Hymenoptera, Argidae): an East Asia pest of elms (Ulmus sp.) invading Europe / S.M. Blank, etc. // European Journal of Entomology. 2010. № 107. P. 357-367.

3. Желоховцев А.Н., Зиновьев А.Г. Список пилильщиков и рогохвостов (Hymenoptera, Symphyta) фауны России и сопредельных территорий // Энтомологическое обозрение. 1995. Т. 74. № 2. С. 395-415.

4. Гниненко Ю.И., Гниненко М.Ю., Раков А.Г. Новые обнаружения ильмового пилильщика-зигзаг в России // Защита и карантин растений. 2013. C. 40-41.

5. A kanyargós szillevéldarázs (Aproceros leucopoda Takeuchi, 1939) magyarországon/ G. Vetek, J. Mikulas, G. Csoka, S. Blank // Növényvédelem. 2010. № 46. P. 519-521.

6. Kraus M., Liston A.D., Taeger A. Die invasive Zick-Zack-Ulmen blattwespe Aproceros leucopoda Takeuchi, 1939 (Hymenoptera: Argidae) in Deutschland // Deutsche Gesellschaft fur allgemeine und angewandte Entomologie, 2011. № 25 (3). P.117-119.

7. Zandigiacomo P., Cargnus E., Villani A. First record of the invasive sawfly Aproceros leucopoda infesting elms in Italy // Bulletin of Insectology. Department of Agroenvironmental Sciences and Technologies, 2011. № 64 (1). P.145-149.

8. Applicability of coloured traps for the monitoring of the invasive zigzag elm sawfly, Aproceros leucopoda (Hymenoptera: Argidae) / G. Véte, etc. // Acta Zoologica Academiae Scientiarum Hungaricae. 2016. № 62(2). P.165-173. D0I: 10.17109/AZH.62.2.165.2016

9. Zig-zagging across Central Europe: recent range extension, dispersal speed and larval hosts of Aproceros leucopoda (Hymenoptera, Argidae) in Germany / S.M. Blank, etc. // Journal of Hymenoptera Research. 2014. № 41. P. 57-74. D0I: 10.3897/JHR.41.8681

10. Мартынов В.В., Никулина Т.В. Вспышка численности ильмового пильльщика-зигзаг Aproceros leucopoda (Takeuchi, 1939): Hymenoptera, Argidae) в Ceверном Приазовье // Русский журнал биологических инвазий. 2017. № 1. С. 25-34.

11. Мартынов В.В., Никулина Т.В. Новые инвазивные насекомые-фитофаги в лесах и искусственных лесонасаждениях Донбасса // Кавказский энтомологический бюллетень. 2016. Том 12. Вып.1. С. 41-51.

12. Ильмовый пилильщик в европейской части России / В.И. Щуров и др. // Защита и карантин растений. 2012. № 2. С. 37-38. 
13. Изменения в фауне перепончатокрылых насекомых Ростовской области и прогноз экологических последствий / К.С. Артохин, П.К. Игнатова, С.И. Колесников, А.А. Решетов // Живые и биокосные системы. 2013. № 2. URL: http://www.jbks.ru/archive/issue-2/article-6

14. Сорокин Н.С. Ильмовый пилильщик в Ростовской области // Защита и карантин растений. 2013. № 11. С. 35-37.

15. Блюммер А.Г. Вязовый пилильщик-зигзаг Аproceros leucopoda Takeuchi, 1939 (Hymenoptera, Argidae) — экономически значимый вредитель вяза из Восточной Азии, расширяющий инвазийный ареал в европейской части России // Карантин растений. Наука и практика. 2015 . № 4 (14). С. 13-16.

16. Ленгесова Н.А., Мищенко А.В. Биология, экология и молекулярно-генетические исследование ильмового пилильщика Aproceros leucopoda (Тakeuchi, 1939) (Hymenoptera: Argidae) — вредителя вяза в (реднем Поволжье // Кавказский энтомологический бюллетень. 2013. № 9(1). С. $163-167$.

17. Papp V., Ladányi M., Vétek G. Temperature-dependent development of Aproceros leucopoda (Hymenoptera: Argidae), an invasive pest of elms in Europe // Journal of Applied Entomology. 2018. № 142. P. 1-9. D0I: 10.1111/jen. 12503

\footnotetext{
○ Филимонова Ольга Сергеевна (olga_filimonova_88@rambler.ru ).

Журнал «Современная наука: актуальные проблемы теории и практики»
}

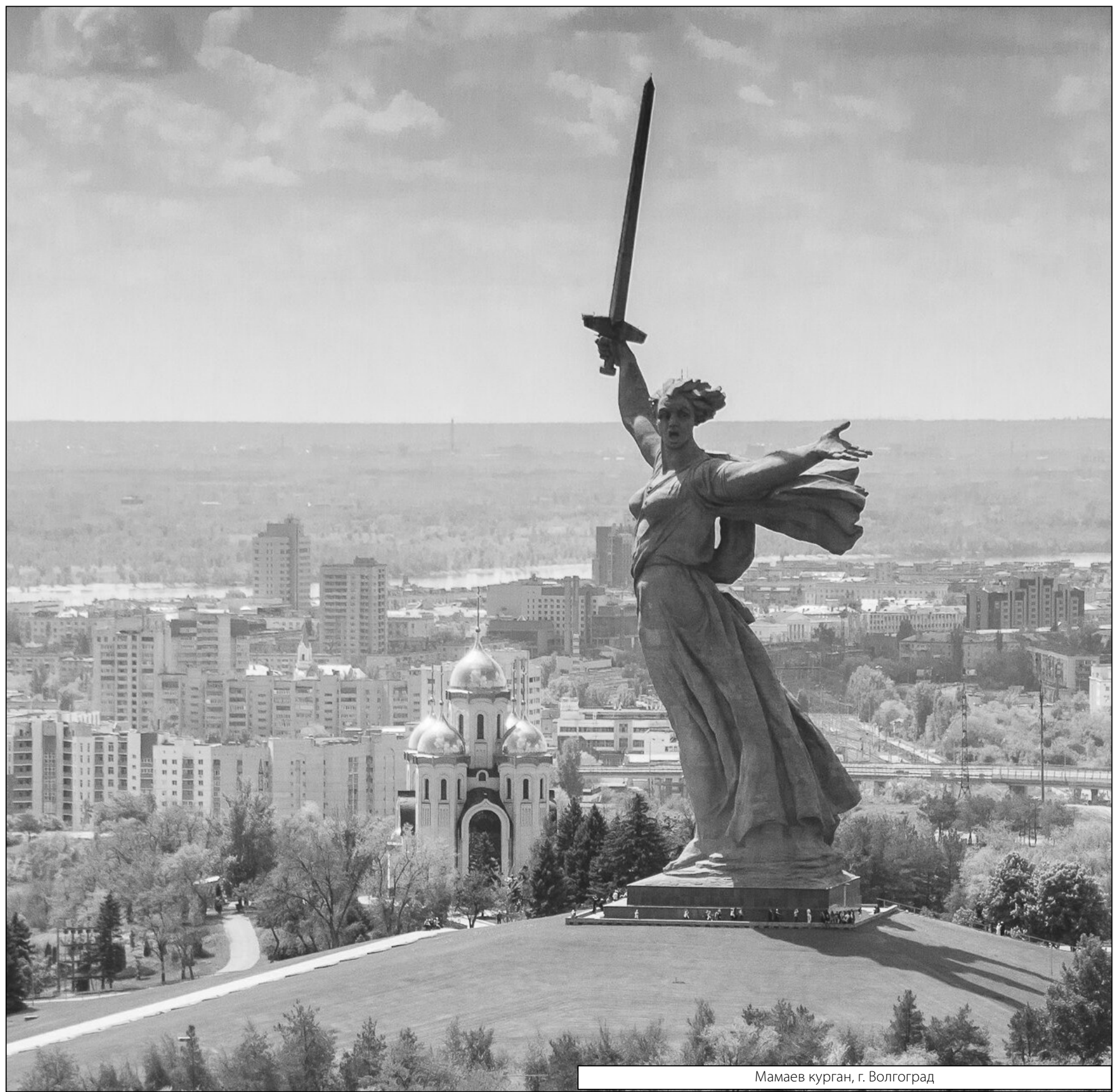

